\title{
DÜBLIN
}

Technological University Dublin

ARROW@TU Dublin

Articles

School of Management

2020

\section{Incentivizing and re-engaging lapsed health club members}

\author{
Teresa Hurley \\ Technological University Dublin, teresa.hurley@tudublin.ie \\ Corinne Faure \\ Grenoble Ecole de Management \\ Seamus Kelly \\ University College Dublin
}

Follow this and additional works at: https://arrow.tudublin.ie/buschmanart

Part of the Business Administration, Management, and Operations Commons, Marketing Commons, Sales and Merchandising Commons, and the Sports Management Commons

\section{Recommended Citation}

Hurley, T., Faure, C. and Kelly, S. (2020), "Incentivizing and re-engaging lapsed health club members", Sport, Business and Management, Vol. 10 No. 5, pp. 545-565. DOI: 10.1108/SBM-10-2019-0094

This Article is brought to you for free and open access by the School of Management at ARROW@TU Dublin. It has been accepted for inclusion in Articles by an authorized administrator of ARROW@TU Dublin. For more information, please contact arrow.admin@tudublin.ie, aisling.coyne@tudublin.ie,gerard.connolly@tudublin.ie.

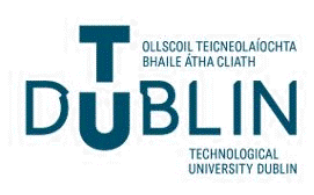




\title{
Incentivizing and re-engaging lapsed health club members
}

Incentivizing health club members

\author{
Teresa Hurley \\ Technological University Dublin, Dublin, Ireland \\ Corinne Faure \\ Grenoble Ecole de Management, Grenoble, France, and \\ Seamus Kelly \\ University College Dublin, Dublin, Ireland
}

Received 15 October 2019 Revised 3 March 2020

4 June 2020

5 June 2020

Accepted 5 June 2020

\begin{abstract}
Purpose - This quantitative research paper examined factors influencing re-engagement intentions and re-engagement behavior of lapsed health club members and identified which sales promotion incentives are most effective in re-engaging this lapsed member market. While previous studies examined reengagement intentions and re-engagement behavior in isolation, no research could be located which examined both simultaneously and the impact of promotion incentives in the health and fitness industry.

Design/methodology/approach - Study A (mail survey) examined re-engagement intentions of one hundred lapsed members of a medium size suburban health club. Study B (an experimental field study) measured actual true re-engagement behavior using price and gift token as incentives to re-engage 300 lapsed members of the same health club. Ten hypotheses were tested using chi-square, logistic regression and correlation analysis.

Findings - Results indicate that price is the most influential incentive in promoting re-engagement intentions, while the experimental field study tested this survey finding and reported that although incentives were more effective than nonincentives in terms of re-engagement behavior, price played a far greater significant role than gift token in actual re-engagement behavior of lapsed members. Highly satisfied customers are likely to have stronger re-engagement intentions with frequent attendees more influenced by price in terms of re-engagement intentions, while those who lapsed most recently demonstrated stronger re-engagement behavior.

Research limitations/implications - Study A: While acknowledging that the sample size was limited, a respectable response rate of $49 \%$ was recorded for the mail survey in Study A but a greater response rate and larger sample size would have allowed for a more comprehensive analysis. However, the study is primarily exploratory in nature and serves to achieve the objectives of the research. The study was based on a medium size suburban health club, therefore no comparisons can be drawn between the results of this study and that involving larger health clubs, chains, urban clubs or those outside of Ireland. Although the inclusion of moderating effects was considered, it was not feasible to develop these interactions due to the limited sample size. Study B: Generalization of the findings in this study with other international markets is not possible due to differences in demographic factors, promotions and differences in the health and fitness industry. No comparison can be drawn either between health clubs which operate in a different environment, such as public or nonmembership-based clubs, urban clubs or those constituting a chain. While the offer incentives were of equal value, it is recognized that the gift token may have appealed more to females than to males.

Practical implications - Health clubs should consider changing strategic focus, from being overly concentrated on new customer acquisition to actively re-engaging the lapsed member market by finding out why they left and offer an incentive such as price to re-engage. Although loyalty, duration, age, gender and income were found not to be significant in this study, satisfaction, frequency and recency of lapse were significant. Therefore, health clubs should strive to keep members satisfied, monitor and increase frequency of attendance with creative programming and commence the re-engagement process prior to the membership expiry so as to maximize re-engagement and customer retention using price discount as an incentive.
\end{abstract}

Originality/value - The originality of this study is that is tests statistically consumer re-engagement intentions and actual re-engagement behavior simultaneously in a health club setting using a mail survey in Study A and Experimental Design in Study B.

Keywords Sales promotion incentives, Re-engagement intentions/behaviors, Lapsed health club members Paper type Research paper

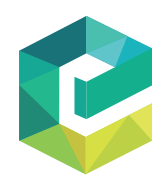

Sport, Business and Management An International Journal Vol. 10 No. 5,2020 pp. $545-565$ 2042-678X DOI 10.1108/SBM-10-2019-0094 
SBM

10,5

546

\section{Introduction/purpose}

Extensive resources are invested in recruiting new members to health and fitness clubs and it is critically important that those new members recruited become long-term patrons. Thus, as a long-term repeat purchase business with a high degree of customer involvement, it seems clear that customer relationship marketing, service recovery and sales promotion, are very appropriate theoretical frameworks to apply to the health and fitness sector. This paradigm offers the potential to inform thinking on issues of customer relationship marketing, customer recovery strategies and promotion incentives.

This is critically important for membership based organizations and it is widely recognized that sports clubs can benefit from relationship marketing, service recovery and sales promotion principles (Cohen, 1996; Hurley, 2005a). Despite this, there appears to be limited research examining the management of membership organizations in terms of these concepts (Gruen et al., 2000) with the exception of case study work in sports organizations (Lapio and Speter, 2000; Cousens et al., 2001). Indeed Stavros (2005) reports the sports industry to be a poor adopter of relationship marketing practices while an over concentration on current versus lapsed membership has also been highlighted.

Although Thomas et al. (2004) examined the role of price in the customer revival process and Koronios et al. (2017) studied motives underlying repeated participation at high performance sports events, Homburg et al. (2007, p. 462) state that "academic research has largely ignored customer relation revival activities" and since these activities play an important role in business practice, this represents a significant "research gap". Ballings and Van den Poel (2012) further encourage companies to change the focus from customer acquisition to customer retention, with Olanrewaju et al. (2016) and Ascarza et al. (2018) examining how to reduce customer churn and improve customer retention management, maximizing profits (Lemmens and Gupta, 2020).

\section{Literature review}

This section provides an overview of the key research areas and authors pertinent to the study including direct marketing, relationship marketing, purchase intentions and customer re-engagement.

\subsection{Direct marketing}

Direct marketing can be described as a relationship that accommodates and nurtures individualized, personalized and interactive customer engagement. Ansari (2011) attributes the success of sales promotion to its direct impact upon consumer purchase behavior and can include monetary and nonmonetary incentives (Vafainia et al., 2017). Lemmens and Gupta (2020) recommend identifying those most likely to disengage and incentivizing them using cash vouchers as an incentive. However, if offering price, the offer needs to be carefully considered as it has been noted how price discounts can have a negative impact including declining quality perceptions, profit erosion, decreased brand equity (Mela et al., 1997; Dark and Chung, 2005) and sales volume and store traffic (Aribarg and Arora, 2008). Some researchers suggest that a promotion threshold or minimum value of price promotion is required to influence consumers' purchase intentions including a minimum $20 \%$ reduction (Gupta and Cooper, 1992; Harlam et al., 1995) with significant differences in response rates between 30 and $40 \%$ discount levels and 10 and $30 \%$ price discounts recorded by Kalwani and Yim (1992) while Thomas et al. (2004) recommended a low reacquisition price followed by a higher price once re-engaged.

Tamaddoni et al. (2017) examined the impact of personalized incentives on the profitability of customer retention campaigns and gift token has been highlighted as an important incentive by some authors (Danaher et al., 2015; Hu et al., 2018). Interesting findings 
have also emerged regarding gender with females more likely than males to participate in gift promotions (Carpenter and Moore, 2008), are more sensitive to relational aspects of a service encounter (Peter and Olsen, 1999), are more loyal (Ndubisi, 2006), and demonstrate greater levels of re-patronage than males (Korgaonkar et al., 1985). However, this conflicts with research by Lichtenstein et al. (1997) who found no significant differences between genders in terms of nonprice promotions.

In contrast, Armstrong and Kotler (2003) emphasized the relationship marketing and customer recovery aspects of sales promotion by defining it as a means of connecting directly with consumers, carefully selected and targeted to achieve an immediate response in order to cultivate long-term relationships. Therefore in order to maximize the benefit of sales promotion to its full potential, marketers must understand the theoretical and practical implications of relationship marketing and service recovery principles and the impact they have upon purchase/re-engagement intentions (Jones et al., 2003) and actual purchase behavior (Seiders et al., 2005; Doorn et al., 2010).

\subsection{Relationship marketing}

Relationship marketing, "activities directed towards building customer loyalty by providing value to all parties involved in the relational exchange" (Peng and Wang, 2006), and service recovery, "the likelihood of using a service provider again in the future" (Boonlertvanich, 2009 , p. 2) have become increasingly important business themes for a host of industries with some researchers promoting them as a significant predictor of future profitability of a firm (Kamakura et al., 2003; Gupta et al., 2006; Yaghoubi et al., 2017). It plays a key role in service industries reliant upon frequent customer usage and repeat patronage or membership such as health clubs.

\subsection{Purchase intentions and influencing variables}

Fishbein and Ajzen (1975) highlighted the importance of understanding consumers' purchase intentions as far back as 1975 maintaining that it is only through intentions that an individual's future behavior can be gauged, for example true or actual purchase behavior or re-engagement. A positive relationship has been identified between satisfaction and re-engagement intention to rejoin and satisfaction and price incentive (Cronin and Taylor, 1994; Söderlund, 2006). Advances in technology including enhanced customer relationship management systems, provides firms with further promotional opportunities (Gruner et al., 2014; Hinz et al., 2011). As a result, there has been an increasing number of studies on targeting strategies (Haenlein and Libai, 2013; Libai et al., 2013; Nejad et al., 2015; Hu et al., 2018).

Other researchers claim that those customers who have bought most recently and most often are most likely to respond favorably to subsequent offers and those who make fewer transactions are more likely to disengage (Hughes, 1996; Schmittlein and Peterson, 1994; Bolton et al., 2000). Thomas et al. (2004) also note how the shorter the lapse duration the greater the propensity to re-engage. Selin et al. (1987) in their study of consumer loyalty in recreation centers and Divett et al. (2003) in a study of theater customers supported the notion that consumers who demonstrate the greatest levels of loyalty had an increased propensity to repeat purchase more often and spend more money. Phua et al. (2017) and Irtema et al. (2017) also identified loyalty as a factor influencing customer intentions to re-engage with Kim and Park (2017) emphasizing how the multifaceted nature of attitudinal loyalty may prove useful for segmenting the recreational sport market.

However, a study by Reinartz and Kumar (2002) found the link between loyalty and profitability for four different companies across different industries to be only weak to moderate while a further report by Kumar et al. (2006) suggests that loyal customers are more

Incentivizing health club members 
SBM

10,5

\section{8}

likely to repeat purchase and accept price increases (Chaudhuri and Ligas, 2009). Furthermore, Fischbach (2006) notes the frequency with which customers use the facility plays a key role in the decision to repurchase in sports centers while Ha and Jang (2010) propose that familiarity moderates customer value, satisfaction and behavioral intentions with other researchers note how frequency influences purchase intentions (Prayag and Grivel, 2014; Loureiro et al., 2014).

Age has also been found to be an influencing factor with older customers more willing to continue relationships with firms, less likely to adjust to new products or services and more willing to return to a previous service provider (Rusbult et al., 1982), while Homburg et al. (2007) note how older customers are more likely to respond positively to customer revival activities than younger customers.

Sudhakar and Rani (2013) note how income does not influence the purchase behavior of personal care products while contrastingly, Janany and Shivany (2017) found income influenced the purchase intentions of customers toward beauty care products. Other researchers report that price increases are likely to affect the purchase behavior of lowincome categories that are less likely to purchase as a result (Homburg et al., 2007). Therefore, lower income categories are likely to be influenced by price incentive in order to re-engage.

\subsection{Customer re-engagement and influencing variables}

However, re-engagement of the lapsed customer remains an overlooked facet of sales promotion, relationship marketing and service recovery theory and practice (Reinartz et al., 2004; Gupta et al., 2006; Rust and Chung, 2006) and it is hoped that this study will provide for new informed thinking on the subject adding to work completed by Thomas et al. (2004) and Homburg et al. (2007). Similar to previous studies, the authors did not examine why customers left or discontinued business and did not seek feedback from lapsed customers regarding appropriate incentives to activate re-engagement prior to testing promotional strategies to re-engage the lapsed member market. According to Homburg et al. (2007) customer relation revival is a neglected area in the literature which requires further investigation.

In another study of intentions, Koronios et al. (2018) reported on motives and constraints of participants in running events using intention as the dependent variable. However, the study did not examine actual behavior. Similarly, Mir and Rehman (2012) report on several studies which have been completed to ascertain how sales promotion techniques influence consumers' perceptions and purchase intentions/behavior. Contrastingly, Ansari (2011) focused on the impact sales promotion can have upon consumer purchase behavior rather than intentions, reporting positive findings. However, according to Lowe and Barnes (2012) greater research is needed, particularly experimental research with real consumers.

Studies to date appear to concentrate on behaviors of current members, in contrast this study focuses on recently lapsed members of a medium size, suburban, private health club and their re-engagement intentions and behavior. This is in line with recommendations for further study from previous researchers seeking greater insight into "customer churn" that could be gained from further analysis of motives and behaviors of customers who recently exited (Ahmad and Buttle, 2002) and recommendations for sports organizations to enhance their understanding of relationship marketing principles (Lachowetz et al., 2001). This research extends beyond previous studies by not just simply testing customer intentions to re-engage but applies specific sales promotion incentives to test actual customer re-engagement behavior, a recommendation extending from the work of Gamliel and Herstein (2011) who studied the impact of price framing on consumers' purchase intentions. 


\section{Re-engagement}

This study sought to:

(1) Examine factors influencing the re-engagement intentions of lapsed health club members (Study A).

(2) Identify factors influencing the actual re-engagement behavior of lapsed health club members and test the effectiveness of sales promotion incentives to re-engage this lapsed member market (Study B).

The conceptual framework for the study is outlined in Figure 1 and builds upon aspects of earlier models adopted by Thomas et al. (2004), Homburg et al. (2007) and Ferrand et al. (2010). These models were selected due to relevance and validity and provided a useful framework upon which to build the hypotheses for the study. The overall study included 10 hypotheses with hypothesis 1, 2, 6, 8 and 9 applicable to both studies, hypothesis 4, 5, 7 and 10 applicable to Study A only, with hypothesis 3 applicable to Study B only. The hypotheses were selected based on access to information and previous research.

H1. (H1A and B) Proposes a relationship between promotion incentive and reengagement intention/behavior of lapsed members with monetary incentives (price) having a greater impact than nonmonetary incentives (gift token; Choi et al., 2010; Nusair et al., 2010; Hu et al., 2018; Els et al., 2019).

H2. (H2A and B) Proposes a relationship between duration of membership and re-engagement intention/behavior with long-term members more likely to re-engage (Fullerton, 2014).

H3. (H3B) Proposes a relationship between recency of membership lapse and re-engagement behavior with recently lapsed members more likely to re-engage (Bolton et al., 2000).

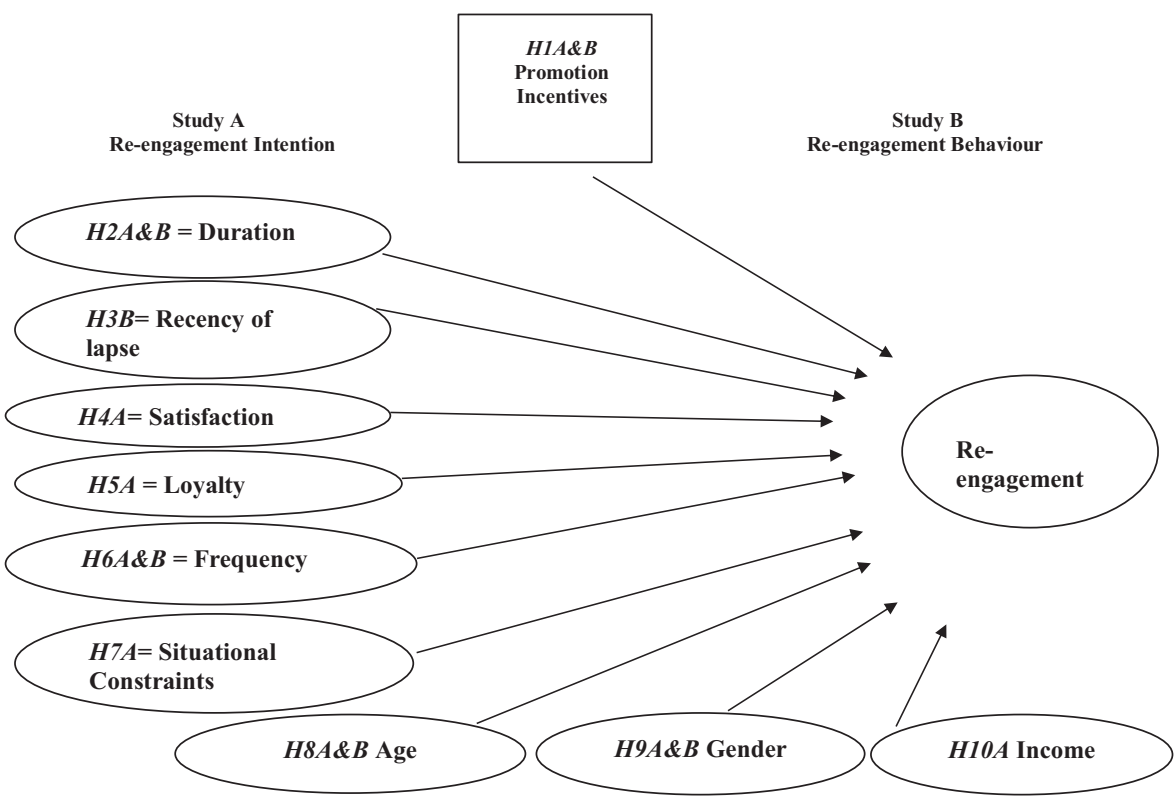

Figure 1. Conceptual framework for the study 
SBM

10,5

H4. (H4A) Proposes a relationship between satisfaction and re-engagement intention with members reporting high satisfaction levels more likely to re-engage (Ferrand et al., 2010; Kalia et al., 2016).

H5. (H5A) Proposes a relationship between behavioral loyalty and re-engagement intention with those who had a previous club membership and exercise history more likely to re-engage (Dwyer, 2011; Phua et al., 2017; Irtema et al., 2017).

H6. (H6A and $B$ ) Proposes a relationship between frequency of usage and re-engagement intentions/behaviour with frequent attendees more likely to re-engage (Prayag and Grivel, 2014; Loureiro et al., 2014).

H7. (H7A) Proposes a relationship between situational constraints including price and nonprice-related reasons for leaving and re-engagement intention with members who discontinue due to price more likely to be incentivized by price to re-engage (Suvattanadilok, 2014).

H8. (H8A and B) Proposes a relationship between age and re-engagement intention/ behavior with older members more likely to re-engage and less likely to be influenced by price or gift token incentives (Homburg et al., 2007; Choi et al., 2010).

H9. (H9A and B) Proposes a relationship between gender and re-engagement intention/ behavior with female members more likely to re-engage than males (Ndubisi, 2006; Moore and Carpenter, 2008).

H10. (H1OA) Proposes a relationship between income and re-engagement intention with lower income earners more likely to be influenced by price incentive to re-engage (Han et al., 2011; Janany and Shivany, 2017; Homburg et al., 2007).

\section{Research design and methodology}

Study $A$ sought to examine factors influencing the re-engagement intentions of lapsed health club members using a mail survey to 100 recently lapsed members $(n=49)$ who had discontinued membership of a medium size, suburban, private health club within the preceding six months. The survey was informed by a focus group session with senior health and fitness operators in Ireland, facilitated at the Irish Institute of Leisure and Amenity Management (ILAM Ireland) annual conference which sought to ascertain industry concerns regarding why members join, member behavior patterns, exit analysis, re-engagement of the lapsed member market and demographic factors. This allowed for valuable input from senior management regarding the proposed study and mail survey content which was subsequently developed, piloted and distributed.

The surveys were dated, edited and coded as returned and the overall statistical descriptive analysis was completed using SPSS. Differences in response rates of early versus late respondents were assessed as per Armstrong and Overton (1977) and no differences were found. A check was also completed for multivariate outliers using SPSS Regression (Mahalanobis Distance) but none were located.

One of the main findings from the survey indicated that price and gift token were considered the most effective sales promotion tools in promoting re-engagement intentions of the lapsed member market and this was further tested in terms of true actual purchase behavior in Study B.

Study $\boldsymbol{B}$ sought to systematically manipulate re-engagement incentives including price discount, gift token and no incentive (control group) through random assignment. The study was set in a real world context and did not just test stated intentions as in Study A, but true behaviors through the use of a field experiment $(n=300)$. Anderson and Simester (2011, 
p. 102) maintain that "companies can gain more from field experiments than from analyzing historical transactions due to the greater accuracy which can be gained from the analysis of data generated in field experiments."

The sample for this study drew upon the same health club that was used for Study A with a sample size of 300 randomly chosen recently lapsed members who discontinued membership within the preceding six months which were randomly assigned to one of three experimental groups; Group 1 was used as the control or baseline group and was not offered any incentive to re-engage; Group 2 was offered a price reduction; Group 3 was offered a gift token. The price incentive and gift token were of equal value at $€ 100$ each incentivizing lapsed members to re-engage. The price incentive included $\mathrm{a} € 100$ reduction on annual health club renewal while the gift token offered $5 \times 1$ hour personal training sessions in the health club or facial and back massage in the salon attached to the health club. It was anticipated that this postal offer would appeal to both male and female markets. The literature review completed on price and gift token helped inform the price and gift token offer format.

A chi-square test was performed to ensure validity of the random assignment procedure of incentives across gender while (ANOVA) was performed to ensure the validity of the random assignment procedure of incentives across number of visits, membership duration, months passed since relapse, age and frequency. The results for all ANOVAs revealed no difference between various groups of respondents. SPSS, chi-square, correlation and logistic regression analysis were used to analyze the results for Study A and B. A summary of the overall research design is outlined in Table 1 below.

The research design, measurement items and analysis for each of the hypotheses is presented separately for Study A in Section 5 and for Study B in Section 6.

\section{Study A - Measurement items and scales}

Intention to re-engage was captured as a single measure item and is consistent with Murray and Howat (2002) and is further supported in terms of validity by Bergkvist and Rossiter (2007). Satisfaction (H4A) as defined and researched by Gotlieb et al. (1994) and Dawes (2008) suggests that most measures of global or overall satisfaction have used a oneitem 5-or 7-point satisfaction scale. In this study, lapsed members were requested to rate their overall satisfaction on a 5-point Likert-type scale ranging from very dissatisfied to very satisfied and is represented in hypothesis four (H4A).

Loyalty was measured as behavioral loyalty and is represented in hypothesis five (H5A) and captured as a multiresponse item incorporating those used in previous studies. Previous purchase behavior was also included in order to test whether there is a positive

\begin{tabular}{lll}
\hline & Study A & Study B \\
\hline Study type & Mail survey & $\begin{array}{l}\text { Experimental field study - no incentive and price and gift } \\
\text { token }\end{array}$ \\
& (1) Industry focus & \\
$\quad$ group & \\
Sample size & $N=49$ & $N=300$ (2) groups) \\
& & (1) $1=$ Control \\
& & (2) $2=$ Price \\
Hypothesis & H1, $3,4,5,6,7,8,9,10$ & H1, $2,3,6,8$ and 9 \\
tested & &
\end{tabular}

\section{tested}

Incentivizing health club members 
SBM

10,5

552

relationship between previous behavioral loyalty and expressed future behavioral loyalty. Previous purchase behavior was measured by length of membership in years from the health club database. It was assumed that lapsed members who had not joined another club since leaving would also be more likely to re-engage, this information was captured as a single measure item.

Situational constraints were captured in the survey as a single measure item using a version of model of switching behavior developed by Keaveney (1995) and Alexandris and Carroll (1999). Respondents were asked to list their top reason for discontinuing membership of the club and this was analyzed as part of hypothesis seven (H7A) and included price and nonprice reasons for leaving the club.

Details regarding membership fees/payment and demographic questions including age, gender, occupation, income, family members, marital status were sought using interval based questions in the survey in Study A as self-reported categories. Income detail (H10A), was sought using an interval-based question whereby members were asked to indicate their annual income by selecting a category.

\subsection{Research findings from Study A}

5.1.1 Descriptive findings. Study A involved a mail survey which was posted to 100 lapsed members who had discontinued membership of a medium size, suburban, private health club within the preceding six months with a response rate of $49 \%$ recorded. Of all the respondents, $77 \%$ were female while $23 \%$ were male. The majority of respondents $(67 \%)$ were aged between 22 and 50 years with only $10 \%$ below 21 years and $23 \%$ above 51 years. Regarding income, $21 \%$ earned less than $€ 10,000$ while the majority ( $48 \%$ ) earned between $€ 20-50,000$ with $11 \%$ earning between $€ 50-100,000$. Sedentary jobs accounted for $48 \%$ while $40 \%$ considered it active.

Fitness was noted by $49 \%$ of members as the main reason for joining a health club in Study A. However, gender differences were noted with $31 \%$ of females joining for weight loss, $31 \%$ for fitness and $6 \%$ to look better. In contrast, $10 \%$ of males joined primarily for fitness, $4 \%$ for weight loss and $6 \%$ for rehabilitation and conditioning. Social reasons did not feature as a priority for joining. While some respondents listed reasons in the "other" category provided, they did not form any coherent pattern to be considered.

Regarding previous exercise history, $90 \%$ of lapsed members reported as somewhat active, passive or did not exercise at all prior to joining the health club, $26 \%$ had been a member of a health club previously while $74 \%$ had never been a member of a health club. All of the $26 \%$ who had been members of health clubs previously had discontinued membership within a six month period.

Membership type noted that $82 \%$ of members had joined for one year with $30 \%$ paying a joining fee and $29 \%$ stating that this was instrumental in extending the duration of the membership with $83 \%$ remaining as members of the club for at least six months. Special offers accounted for $12 \%$ which indicates that members can be incentivized to join health clubs but does not tell us which promotions are most effective.

Attendance indicated female members to be more active members for longer periods of time and more regular in attendance than male counterparts who as a consequence are more predisposed to discontinuing membership. Lower attendance was reported for Spring and Summer.

Respondents discontinued membership of the health club due to situational factors $(23 \%)$, club related reasons $(20 \%)$, time limitations $(17 \%)$, boredom $(10 \%)$, injury/illness $(8 \%)$, price $(6 \%)$ with $16 \%$ not responding to the question. These situational factors are examined further as part of hypothesis (7A). A significant number of lapsed members had not rejoined another health club since discontinuing membership (85\%) while 54\% stated they would 
consider rejoining the same health club. Possible reasons and incentives for rejoining are explored in the hypothesis test section.

Satisfaction levels indicated that a significant number of lapsed members were either satisfied $(88 \%)$ or very satisfied with $66 \%$ stating that the health club in question could have done nothing to prevent them from discontinuing membership.

5.1.2 Hypothesis testing. Promotion incentives were tested as part of hypothesis one (H1A and B) which proposed a relationship between promotion incentive and re-engagement intentions/behavior of lapsed members with monetary incentives (price) having a greater impact than nonmonetary incentives (gift token).

In Study A, (H1A) could not be directly tested. Instead, responses to some of the questions were used as preliminary evidence for this hypothesis. Respondents were asked whether they would reconsider rejoining the club and $22 \%$ out of 49 respondents $(44.9 \%)$ stated that they would do so. In a subsequent question, respondents were asked which type of incentive would help convince them to rejoin the club. Of all the respondents, 21 respondents $(95 \%$ of those considering rejoining the club) stated that a price incentive would motivate them to rejoin the club, while only four respondents (18\% of those considering rejoining the club) agreed that a gift token would do so. Other possible incentives proposed were either never chosen or only mentioned by one respondent. While this finding represents re-engagement intentions only and only provides circumstantial evidence for the notion that price incentives are more effective than gift incentives in reactivating lapsed members, the finding is consistent with the hypothesis which will be tested more formally in Study B.

Membership duration was tested in hypothesis two (H2A and B) which proposed a relationship between duration of membership and re-engagement intention/behavior with longterm members more likely to re-engage.

A correlation analysis (Table 1 Appendix A) was performed to analyze the association between membership duration and effect of price/gift incentives on re-engagement intention and the correlation was found to be nonsignificant (Price: $r=-0.101, n=40, p$-value $=0.534$, Gift: $r=0.140, n=40, p$-value $=0.390$ ). Therefore duration has no significant impact on member re-engagement intentions and is not influenced by promotion incentive and hypothesis (2A) is not supported.

Hypothesis 3-Recency of lapse was not measured in Study A but instead was tested as part of Study B.

Hypothesis four (H4A) proposes a relationship between satisfaction and re-engagement intention with members reporting high satisfaction levels more likely to re-engage.

Correlation analysis was performed to analyze the association between satisfaction and intention to re-engage, and the correlation was found significant at the level of $10 \%(r=0.33$, $n=33, p$-value $=0.061)$. Furthermore, the correlation between satisfaction with the club to price/gift was analyzed and the correlation was found significant for price $(r=0.38, n=40$, $p$-value $=0.016)$, but not significant for gift $(r=-0.196, n=40, p$-value $=0.225)$ as outlined in Table 2 Appendix A. This supports hypothesis (4A) demonstrating the greater the satisfaction levels the greater the re-engagement intention and the more likely the member is to be influenced by price to re-engage.

Loyalty was measured as behavioral loyalty and is represented in hypothesis five (H5A) which proposes a relationship between behavioral loyalty and re-engagement intention with those who had a previous club membership and exercise history more likely to re-engage.

Correlation analysis (Table 3 Appendix A) was performed to analyze the association between previous exercise pattern and intention to re-engage, where the correlation was found nonsignificant $(r=-0.036, n=33$, $p$-value $=0.844)$. Furthermore, a chi-square test was performed to study the association between previous club membership and the effect of price/gift where both were found nonsignificant (Price: chi-square $=0.003$, df $=1$, $p$-value $=0.956$, Gift: chi-square $=1.75, \mathrm{df}=1, p$-value $=0.249)$. This indicates that loyalty
Incentivizing health club members 
SBM

10,5

does not impact upon re-engagement intention of members in any significant manner, the hypothesis is not supported.

Frequency was tested in hypothesis six (H6A and B) which proposed a relationship between frequency of usage and re-engagement intention/behavior with frequent attendees more likely to re-engage.

Correlation analysis was performed to analyze the association between frequency of club visits and re-engagement intention and was found nonsignificant $(r=-0.064, n=27$, $p$-value $=0.751)$. However, the correlation between frequency of club visits to price/gift was analyzed and was found significant for price $(r=0.51, n=31, p$-value $=0.004)$, but not significant for gift $(r=-0.10, n=31$, $p$-value $=0.59)$. This suggests a link between price incentive and frequency with frequent attendees likely to have higher levels of re-engagement intention and to be more influenced by price incentive to re-engage as outlined in Table 4 Appendix A.

Hypothesis seven (H7A) was tested in Study A; it proposes a relationship between situational constraints including price and nonrelated price reasons for leaving and intention to re-engage with members who discontinue due to price related constraints more likely to re-engage if offered a price incentive.

Before testing this hypothesis, respondent's reasons for disengaging were recoded into two categories, linked to price or other reasons. A chi-square test was performed to study the association between the reasons for discontinuing membership and the effect of price/gift. Price was found to be significant at the level of $10 \%$ (Chi-square $=3.74, \mathrm{df}=1, p$-value $=0.06$, while gift was not significant: (Chi-square $=0.399, \mathrm{df}=1, p$-value $=0.482$ ) as outlined in Table 5 Appendix A. This indicates that lapsed members are more likely to re-engage when the reason for leaving is linked to price which implies they are also more likely to be influenced by price incentive to re-engage.

Hypothesis eight (H8A and B) proposes a relationship between age and re-engagement intention/behavior with older members more likely to re-engage and less likely to be influenced by price or gift token incentives.

A correlation analysis was performed to analyze the association between age and the effect of price/gift on re-engagement intention and was found not to be significant (Price: $r=-0.096, n=40, p$-value $=0.558$, Gift: $r=-0.070, n=40, p$-value $=0.667$ ) which indicates that age does not correlate with re-engagement intentions and is not influenced by promotion incentive, the hypothesis is not supported (Table 6 Appendix A).

Hypothesis nine (H9A and B) proposes a relationship between gender and re-engagement intention/behavior with female members more likely to re-engage than males.

A chi-square test was performed to analyze the association between gender and reengagement intentions. This relationship was found to be nonsignificant (Chi-square $=0.117$, $\mathrm{df}=1, p$-value $=0.531$. . This indicates that there is no relationship between gender and reengagement intention and is not influenced by promotion incentive, therefore the hypothesis is not supported.

Hypothesis ten (H1OA) proposes a relationship between income and re-engagement intention with lower income earners more likely to be influenced by price incentive to re-engage.

Income versus intention to re-engage was analyzed using chi-square analysis as outlined in Table 7 Appendix A. Income categories were recoded into a smaller number of categories so that the minimum cell count assumption associated with chi-square analysis was met. Once recoded, the cross-tabulation and chi-square analysis was conducted. While the results of the chi-square test were not significant $\left(X^{2}=1.368, \mathrm{df}=2, p=0.505\right)$, it can be seen from the cross-tabulation that those earning between $€ 21,000$ and $€ 40,000$ are most likely to reengage with the health club.

One of the main findings from the survey indicated that price and gift token were considered the most effective sales promotion tools in promoting re-engagement intentions of 
the lapsed member market and this was further tested in terms of true actual purchase behavior in Study B.

\section{Study B - Measurement items and scales}

Re-engagement behavior and promotion incentives $(\mathrm{H} 1 \mathrm{~B})$ was measured as true actual purchase behavior using a field experiment in Study B. Re-engagement was measured on the basis of internal membership records in the health club with an objective yes/no effectiveness measure related to the question whether or not the customer renewed membership within the last six months so as to provide consistency in the reporting of the results. Recency of lapse (H3B) was captured as an objective measure from the time the membership lapsed on the club database system and after one month was checked to see who returned.

\subsection{Research findings from Study B}

6.1.1 Sample-Study B. The sample for this study drew upon the same health club that was used for Study A with a sample size of 300 randomly chosen lapsed members who discontinued membership within the preceding six months randomly assigned to one of three experimental groups. Group 1 was used as the baseline group and was not offered any incentive to re-engage. Group 2 was offered a price reduction, while Group 3 was offered a gift token. The average age of the sample was 43 years, $47 \%$ male and $53 \%$ female with $78 \%$ being members for between two and five years.

\subsection{Validity check for random assignment of Study B}

Before proceeding with the analysis of Study B, the validity of the random assignment procedure was checked to demonstrate the experimental groups were equivalent to one another before the experimental manipulations. The experimental groups were compared on background variables such as socio-demographic variables (gender and age) but also previous history with the club (membership duration, total number of visits, months passed since relapse, frequency of visits) as outlined in Table 8 Appendix A.

A chi-square test was performed to ensure validity of the random assignment procedure of incentives across gender. The result revealed no significant association between incentives and gender (Chi-square $=0.027, \mathrm{df}=2, p$-value $=0.987)$. Furthermore, analysis of variance (ANOVA) was performed to ensure the validity of the random assignment procedure of incentives across number of visits, membership duration, months passed since relapse, age and frequency. The results for all ANOVAs revealed no difference between various groups of respondents as outlined in Table 9 Appendix A. These analyses provided evidence for the success of the random assignment procedure and demonstrated that the experimental groups were equivalent to one another on those two criteria before the experimental manipulation.

\subsection{Hypotheses analysis for Study B}

Promotion incentives were tested as part of hypothesis one (H1A and B) which proposed a relationship between promotion incentive and re-engagement intentions/behavior of lapsed members with monetary incentives (price) having a greater impact than nonmonetary incentives (gift token).

6.3.1 Study B-Hypothesis (1B). Three experimental groups were compared; Group 1 acted as a control group and received no incentive to rejoin, Group 2 received a price incentive to rejoin, while Group 3 received a gift token incentive to rejoin. The results of this manipulation led to strong differences across groups. While none of the lapsed members of the control 
SBM

10,5

group had rejoined the club after a month, $3 \%$ of the members of the gift token group and $27 \%$ of the price incentive group had rejoined the club (Table 10 Appendix A).

A chi-square test was performed to statistically test the association between promotion incentives and re-engagement behavior. This test showed that the differences between groups were statistically different (Chi-square $=48.667, \mathrm{df}=2, p$-value $<0.001)$. Eliminating the control group to directly compare the price incentive with the gift token group, a further chi-square analysis revealed an association between type of incentive (price/gift) and reengagement behavior with a significantly higher rate of re-engagement behavior influenced by price incentive (Chi-square $=22.588, \mathrm{df}=1, p$-value $<0.001$ ). This supports hypothesis (1B) and confirms that offering an incentive is better than offering no incentive and that price is more effective than gift token in re-engaging the lapsed member market.

In Study B, most of the hypotheses were tested through a logistic regression, with actual rejoining behavior as dependent variable and the information obtained from the club's database as independent variables. The results of this regression are outlined in Table 11 Appendix A and will be discussed for each variable independently. In this analysis, the use of a price incentive was entered as a dummy variable in the equation. Consistent with the chi-square analyses reported beforehand, this variable was found to influence the likelihood to rejoin the club, with lapsed members more likely to rejoin when exposed to a price incentive than otherwise (the incentive accounted for between 15.9 and $33.2 \%$ of the variance). However, results may have been impacted by the heavy weighting of the sample toward having not responded to the incentive.

Membership duration was tested in hypothesis two (H2A and B) which proposed a relationship between duration of membership and re-engagement intention/behavior with longterm members more likely to re-engage.

The logistic regression reported earlier shows that no significant effect of membership duration on rejoining behavior was found (odds ratio $=0.998, p>0.8$ ). This result is consistent with the one found in Study A and confirms that membership duration does not impact re-engagement behavior. Therefore hypothesis (2B) is not supported.

Recency of lapse was tested in hypothesis three (H3B) which proposed a relationship between recency of membership lapse and re-engagement behavior with recently lapsed members more likely to re-engage.

The results of the logistic regression reported earlier revealed that relapse time was close to achieving significance (odds ratio $=0.764$, $p$-value $=0.119$ ). Since it appeared difficult to obtain significant results on the basis of the entire sample (given that only those members who had been exposed to a price incentive were likely to rejoin the club), a further analysis was conducted using only those members who had been exposed to the price incentive. In line with expectations, recency of relapse significantly affected the likelihood to rejoin the club (odds ratio $=0.718, p=0.085$ ). Consistent with the hypothesis, lapsed members were found to be less likely to re-engage as the relapse time increased (Table 12 Appendix A). However, results may have been impacted by the heavy weighting of the sample toward having not responded to the incentive and although the sample size was relatively small, the findings are considered relevant given the exploratory nature of the study.

6.3.2 Hypothesis 4-Satisfaction was not measured in Study B. Frequency was tested in hypothesis six (H6A and B) which proposed a relationship between frequency of usage and re-engagement intention/behavior with frequent attendees more likely to re-engage.

Logistic regression was used to test the effects of frequency of attendance on reengagement behavior. This analysis shows no correlation between frequency and reengagement (odds ratio $=1.044, p>0.8$ ). Therefore hypothesis $6 \mathrm{~B}$ is not supported.

6.3.3 Hypothesis 7 - Situational factors were not measured in Study B. Hypothesis eight (H8A and B) proposes a relationship between age and re-engagement intention/behavior with 
older members more likely to re-engage and less likely to be influenced by price or gift token incentives.

In Study B, the effects of age were tested through the logistic regression reported earlier. The results indicate no correlation between age and re-engagement behavior (odds ratio $=0.996, p>0.8)$. Therefore hypothesis $8 \mathrm{~B}$ is not supported.

Hypothesis nine (H9A and B) proposes a relationship between gender and re-engagement intention/behavior with female members more likely to re-engage than males.

The results of the logistic regression showed no relationship between gender and likelihood to rejoin (odds ratio $=1.59, p$-value $>0.29$ ). Therefore hypothesis $(9 \mathrm{~B})$ was not supported.

A summary of the research findings from Study A and Study B hypotheses is outlined in Table 2 below.

\section{Discussion}

Overall, the hypotheses analyses completed in Study A and B found complementary results, with generally the same factors appearing to have a significant impact on re-engagement behavior across both studies. These findings are discussed for each of the hypotheses in the next section.

The results are highly significant with the survey noting for promotion incentive that price was the most influential incentive in promoting re-engagement intentions of lapsed members. The experimental field study tested this survey finding further and reported that although incentives were more effective than nonincentives in terms of re-engagement behavior, price played a far greater significant role than gift token in actual re-engagement behavior of lapsed members with $27 \%$ of lapsed members in this study incentivized by price to re-engage as compared to only 3\% incentivized by gift and $0 \%$ re-engaging when offered no incentive (H1A and B). Therefore health clubs should offer incentives for members to reengage and price is considered to be most impactful, particularly if the member has disengaged due to price constraints.

Duration (H2A and B) found no significant difference between various lengths of membership duration for those who responded to price and those who did not. However, $29 \%$ of those who paid a joining fee stated that this was instrumental in extending the duration of the membership with $83 \%$ remaining as members of the club for at least six months. Health clubs should therefore consider the value of joining fees in extending the term of the membership.

Recency of lapse $(\mathrm{H} 3 \mathrm{~B})$ was found to be significant indicating that the longer the time of lapse, the less likely the lapsed member is to re-engage. Therefore health clubs should initiate the rejoining process prior to expiry, offering an incentive for members to continue membership of the club with price discount being the most impactful. Griffin and Lowerstein

Study A - Re-engagement intentions

H1. Price - type of incentive is significant with price cited more often than gift

H2. Duration - not significant

H3. Recency of lapse N/A

(1) H4 Satisfaction and intention to rejoin significant at the $10 \%$ level

(2) Satisfaction and price - significant at the $5 \%$ level
Incentivizing health club members

(n)


SBM

10,5

(2001) support the notion of making the re-engagement offer prior to membership expiry, suggesting a 60-70\% chance of successfully repeat selling to an "active customer," 20-40\% to a "lost customer" and 5-20\% to a "new customer." They also calculate the net return on a new customer from an external source at $23 \%$ as compared to $214 \%$ return on investment from the reinstatement of an internal lapsed customer. Therefore, health clubs should concentrate on re-engaging lapsed members as opposed to seeking new members and commence the re-engagement process prior to membership expiry.

A re-engagement model identified as early as the 90s by Stauss and Friege (1999) could be adopted whereby health clubs invest time in completing a re-engagement analysis (identifying who lapsed and why), re-engagement actions (contacting lapsed members and offering incentives to re-engage) and re-engagement controls (evaluating and costing the reengagement process). However, some authors have noted how it may not be effective to reengage all lapsed customers (Griffin and Lowenstein, 2001) emphasizing how the lifetime value of the customer is also an important consideration.

A positive relationship was noted between Satisfaction and Re-engagement Intention to rejoin ( $\mathrm{H} 4 \mathrm{~A})$ and between Satisfaction and Price Incentive. Therefore the more satisfied the customer the greater the re-engagement propensity and likelihood to be incentivized by price to re-engage. Health clubs should therefore strive to increase customer satisfaction levels.

No relationship was found between Loyalty and Re-engagement Intention or between Loyalty and Promotion Incentive (H5A). However, Dwyer (2011) highlights the importance of niche marketing and segmentation in a sporting context and this should be considered by health and fitness operators in order to implement specific targeted marketing campaigns which have more impact and are more cost effective.

Although the results from Study A did not highlight social reasons as a reason for joining the club initially, it is likely that members who develop a social connection with the club are probably less likely to discontinue membership. Health clubs should therefore consider providing social bonding opportunities between members as part of their overall retention strategy.

Frequency and price incentive for re-engagement intention (H6A) had a positive relationship with frequent attendees reporting lower intentions to leave and higher intentions to re-engage. However, there is no evidence from this study that frequency is linked to re-engagement behavior which is surprising and contrasts with research by Ha and Jang (2010) who noted how familiarity moderated customer value, satisfaction and behavioral intentions. Health clubs should strive to increase frequency of visits to the club with creative programming and competitions to encourage patronage and heighten re-engagement intentions.

Situational factor findings (H7A) indicate a relationship between the reasons why people left the club and their intention to rejoin. They are willing to rejoin when the reason for leaving is linked to price issues and price is offered as an incentive to re-engage. Gift incentive was found not to be significantly related. In study A, $23 \%$ of respondents cited situational factors, $20 \%$ club reasons, $17 \%$ time limitations, $10 \%$ boredom, $8 \%$ injury/illness while $6 \%$ noted price as reasons for discontinuing membership. The findings are note-worthy emphasizing how health clubs can improve customer retention by one-fifth by simply reviewing how the club is managed.

Age was found to have no impact upon re-engagement intention or behavior but appears to be inconsistent with other literature which found older customers more willing to continue relationships with firms, less likely to adjust to new products or services and more willing to return to a previous service provider (Homburg et al., 2007). However, age has also been found in other studies to be the most consistent of the demographic factors influencing participation in nonprice promotions with younger audiences more likely to respond to nonprice 
promotions (Carpenter and Moore, 2008). Health clubs should therefore consider demographic factors in developing promotional campaigns.

Gender was found not to have an impact upon re-engagement intention or behavior which again appears inconsistent with other research results which suggests that females are more likely than males to participate in gift promotions (Carpenter and Moore, 2008) and are more loyal (Ndubisi, 2006).

Results for Income were not significant for re-engagement intention in Study A. This compares with findings by Sudhakar and Rani (2013) who noted how income does not influence the purchase behavior of personal care products. It has been noted by other researchers however that price increases are likely to affect the purchase behavior of low income categories that are less likely to purchase as a result (Homburg et al., 2007). Therefore we can assume that lower income categories are likely to be influenced by price incentive in order to re-engage.

\section{Conclusion and implications for research}

The results of this study are significant offering new informed thinking regarding incentivizing and re-engaging lapsed health club members from a theoretical and practical perspective. No theoretical study could be located which tested re-engagement intentions and true actual re-engagement behavior simultaneously in a health club setting.

Health clubs should consider changing strategic focus, from being overly concentrated on new customer acquisition to actively re-engaging the lapsed member market by finding out why they left through an exit analysis with disengaged members. This provides an opportunity to engage with previous members and if disengagement is linked to price, offer a price incentive to re-engage, as offering an incentive to re-engage was found to be more impactful than offering no incentive, regardless of the reason for disengaging. Joining fees appear to be only effective in encouraging members to remain as members up to six months so health club providers should consider the value of joining fees in extending the term of the membership.

Although loyalty, duration, age, gender and income were found not to be significant in this study, satisfaction, frequency and recency of lapse were significant. Therefore, health clubs should strive to keep members satisfied, monitor and increase frequency of attendance with creative programming/competitions and commence the re-engagement process prior to the membership expiry so as to maximize re-engagement and customer retention using price discount as an incentive.

Exceptional customer service and management of the health club will also help alleviate customer disengagement. An accurate membership database is essential and must be managed effectively in order to maximize return from the lapsed member market. Advanced technology systems today provide comprehensive membership details to assist with this process and must be embraced by the health and fitness industry. This provides the added bonus of allowing for different types of promotions to be offered to different segments of the market. Dwyer (2011) highlights the importance of niche marketing and segmentation in a sporting context and these should be considered by health and fitness operators in order to implement specific targeted marketing campaigns which have more impact and are more cost effective.

Although the results from Study A did not highlight social reasons as a reason for joining the club initially, it is likely that members who develop a social connection with the club are probably less likely to discontinue membership. Health clubs should provide for social bonding opportunities between members as part of their overall retention strategy.

Traditionally health clubs have been preoccupied with gaining new members rather than reactivating lapsed members with less than $52 \%$ of health club owners actively seeking to
Incentivizing health club members 
SBM

10,5

re-engage the lapsed member market (Hurley, 2005b). A change of strategy is required if health clubs are to survive in an increasingly competitive environment and monitoring and managing the lapsed member market and recency of lapse is an essential part of this strategy.

\section{Limitations}

Study A: While acknowledging that the sample size was limited, a respectable response rate of $49 \%$ was recorded for the mail survey in Study A but a greater response rate and larger sample size would have allowed for a more comprehensive analysis. However, the study is primarily exploratory in nature and serves to achieve the objectives of the research. The study was based on a medium size suburban health club, therefore no comparisons can be drawn between the results of this study and that involving larger health clubs, chains, urban clubs or those outside of Ireland. Although the inclusion of moderating effects was considered, it was not feasible to develop these interactions due to the limited sample size.

Study B: Generalization of the findings in this study with other international markets is not possible due to differences in demographic factors, promotions and differences in the health and fitness industry. No comparison can be drawn either between health clubs which operate in a different environment, such as public or nonmembership based clubs, urban clubs or those constituting a chain. While the offer incentives were of equal value, it is recognized that the gift token may have appealed more to females than to males.

\section{Future research}

Future studies could seek to examine in greater detail why members discontinue membership of health clubs and demographic factors which might be key to promoting participation in various re-engagement promotions. This research is crucial in determining new differentiation strategies and competitive advantage that can be obtained through specific promotional campaigns targeting specific customer segments. Future studies could also examine the impact different types of price incentives have on various different lapsed member profiles using different framing structures, and the development of loyalty profiles of customers that could be differentiated on the basis of socio-demographic characteristics. Additional variables could also be incorporated and tested in the model including value, sacrifice and quality of the service. The study examines behavioral loyalty only; future studies could include attitudinal and emotional loyalty. Further studies could also examine consumer behavior patterns of those members who re-engage short-term versus long-term and a qualitative study could be incorporated in order to ascertain richer data regarding those who re-engaged versus those who did not re-engage.

\section{References}

Ahmad, R. and Buttle, F. (2002), "Customer retention management: a reflection of theory and practice", Marketing Intelligence and Planning, Vol. 20 No. 3, pp. 149-161, doi: 10.1108/02634500210428003.

Alexandris, K. and Carroll, B. (1999), "Constraints on recreation sport participation in adults in Greece: implications for providing and managing sport services", Journal of Sport Management, Vol. 13 No. 2, pp. 317-332, doi: 10.1123/jsm.13.4.317.

Anderson, E.T. and Simester, D. (2011), “A step-by-step guide to smart business”, Harvard Business Review, Vol. 25, p. 6, doi: 10.1108/dlo.2011.08125faa.011.

Ansari, S. (2011), "The effect of sales promotion on consumer interest to purchase in IKCO automotive company", Journal of Knowledge Management, Economics and Information Technology, Vol. 4, pp. 1-17. 
Aribarg, A. and Arora, A. (2008), "Brand portfolio promotions", Journal of Marketing Research, Vol. 45 August, pp. 391-402.

Armstrong, G. and Kotler, P. (2003), Marketing - an Introduction, Prentice Hall, London.

Armstrong, J.S. and Overton, T.S. (1977), "Estimating non-response bias in mail surveys", Journal of Marketing Research, Vol. 14, pp. 396-402.

Ascarza, E., Neslin, S.A., Netzer, O., Anderson, Z., Fader, P.S., Gupta, S., Hardie, B.G.S., Lemmens, A., Libai, B., Neal, D., Provost, F. and Schrift, R. (2018), "In pursuit of enhanced customer retention management: review, key issues, and future directions", Customer Needs and Solutions, Vol. 5, pp. 65-81, doi: 10.1007/s40547-017-0080-0.

Ballings, M. and Van den Poel, D. (2012), "Customer event history for churn prediction: how long is long enough?”, Expert Systems with Applications, Vol. 39 No. 18, pp. 13517-13522, doi: 10.1016/j. eswa.2012.07.006.

Bergkvist, L. and Rossiter, J. (2007), "The predictive validity of multiple-item versus single-item measures of the same constructs", Journal of Marketing Research, Vol. 44 No. 2, pp. 175-184, doi: 10.1509/jmkr.44.2.175.

Bolton, R.N., Kannan, P.K. and Bramlett, M.D. (2000), "Implications of loyalty program membership and service experiences for customer retention and value", Journal of the Academy of Marketing Science, Vol. 28 No. 1, pp. 95-108, doi: 10.1177/0092070300281009.

Boonlertvanich, K. (2009), "A conceptual model for the repurchase intentions in the automobile service industry: the role of switching bariers in satisfaction - repurchase intentions relationship", International Journal of Business Research, Vol. 9 No. 6, pp. 1-18.

Carpenter, J.M. and Moore, M. (2008), "US consumers' perceptions of non-price retail promotions", International Journal of Retail \& Distribution Management, Vol. 36 No. 2, pp. 111-123, doi: 10. 1108/09590550810853066.

Chaudhuri, A. and Ligas, M. (2009), "Consequences of value in retail markets", Journal of Retailing, Vol. 85 No. 3, pp. 406-419, doi: 10.1016/j.jretai.2009.05.006.

Choi, S., Ge, X. and Messinger, P.R. (2010), "Consumer perceptions of ambiguous price promotions: scratch and save promotions versus tensile price claims", The Journal of Product and Brand Management, Vol. 19 No. 7, pp. 477-486, doi: 10.1108/10610421011086892.

Cohen, A. (1996), "Delivering a one-two punch", Sales and Marketing Management, Vol. 148 No. 6, p. 30.

Cousens, L., Babiak, K. and Slack, T. (2001), "Adopting a relationship marketing paradigm: the case of the National Basketball Association”, International Journal of Sports Marketing and Sponsorship, Vol. 2 No. 4, pp. 331-355, doi: 10.1108/ijsms-02-04-2001-b006.

Cronin, J. and Taylor, S. (1994), "SERVPERF versus SERQUAL: reconciling performance-based perceptions-minus-expectations measurement of service quality", Journal of Marketing, Vol. 58 No. 1, pp. 125-131, doi: 10.1177/002224299405800110.

Danaher, P.J., Smith, M.S., Ranasinghe, K. and Danaher, T.S. (2015), "Where, when, and how long: factors that influence the redemption of mobile phone coupons", Journal of Marketing Research, Vol. 52 No. 5, pp. 710-725, doi: 10.1509/jmr.13.0341.

Dark, P. and Chung, C. (2000), "Effects of pricing and promotion on consumer perceptions: it depends on how you frame it", Journal of Retailing, Vol. 81 No. 1, pp. 35-47.

Dawes, J.G. (2008), "Do data characteristics change according to the number of scale points used? An experiment using 5 point, 7 point and 10 point scales", International Journal of Market Research, Vol. 51 No. 1, pp. 61-104, doi: 10.1177/147078530805000106.

Divett, M., Crittenden, N. and Henderson, R. (2003), “Actively influencing consumer loyalty”, Journal of Consumer Marketing, Vol. 20 No. 2, pp. 109-126, doi: 10.1108/07363760310464587.
Incentivizing health club members 
SBM 10,5

Doorn, J., Lemon, K.N., Mittal, V., Naas, S., Pick, D., Pirner, P. and Verhoef, C. (2010), "Customer engagement behavior: theoretical foundations and research directions", Journal of Service Research, Vol. 13 No. 3, pp. 253-266, doi: 10.1177/1094670510375599.

Dwyer, B. (2011), "Divided loyalty? An analysis of fantasy football involvement and fan loyalty to individual National Football League (NFL) teams", Journal of Sport Management, Vol. 25 No. 5 , pp. 445-457, doi: 10.1123/jsm.25.5.445.

Ferrand, A., Robinson, L. and Valette-Florence, P. (2010), "The intention- to- repurchase paradox: a case of the health and fitness industry”, Journal of Sport Management, Vol. 24 No. 1, pp. 83-105, doi: 10.1123/jsm.24.1.83.

Fischbach, A.F. (2006), "Ramping up retention”, Fitness Business, December, pp. 49-56.

Fishbein, M. and Ajzen, L. (1975), Belief, Attitude, Intention, and Behavior: An Introduction to Theory and Research, Addison-Wesley, Reading.

Fullerton, G. (2014), "The moderating effect of normative commitment on the service quality-customer retention relationship", European Journal of Marketing, Vol. 48 Nos 3/4, pp. 657-673, doi: 10. 1108/EJM-06-2011-0333.

Gamliel, E. and Herstein, R. (2011), "To save or to lose: does framing price promotion affect consumers' purchase intentions?", Journal of Consumer Marketing, Vol. 28 No. 2, pp. 152-158.

Gotlieb, J.B., Grewal, D. and Brown, S.W. (1994), "Consumer satisfaction and perceived quality: complimentary or divergent constructs?”, Journal of Applied Psychology, Vol. 79 No. 6, pp. 875-885, doi: 10.1037/0021-9010.79.6.875.

Griffin, J. and Lowenstein, M.W. (2001), Customer Win-Back: How to Recapture Lost Customers and Keep Them Loyal, Jossey-Bass, San Francisco, doi: 10.1108/jcm.2002.19.1.74.1.

Gruen, T.W., Sommers, J.O. and Acito, E. (2000), "Relationship marketing activities, commitment, and membership behaviours in professional associations", Journal of Marketing, Vol. 64 No. 3, pp. 34-49, doi: 10.1509/jmkg.64.3.34.18030.

Gruner, R.L., Homburg, C. and Lukas, B.A. (2014), "Firm-hosted online brand communities and new product success", Journal of the Academy of Marketing Science, Vol. 42, pp. 29-48, doi: 10.1007/ s11747-013-0334-9.

Gupta, S. and Cooper, L.G. (1992), "The discounting of discount and promotion thresholds", Journal of Consumer Research, Vol. 19 December, pp. 401-411.

Gupta, S., Hanssens, D., Hardie, B., Kahn, W., Kumar, V. and Nathaniel, L. (2006), "Modeling customer lifetime value", Journal of Service Research, Vol. 9 No. 2, pp. 139-155, doi: 10.1177/ 1094670506293810

Ha, J. and Jang, S.C. (2010), "Perceived values, satisfaction, and behavioral intentions: the role of familiarity in Korean restaurants", International Journal of Hospitality Management, Vol. 29 No. 1, pp. 2-13, doi: 10.1016/j.jhm.2009.03.009.

Haenlein, M. and Libai, B. (2013), "Targeting revenue leaders for a new product", Journal of Marketing, Vol. 77 No. 3, pp. 65-80, doi: 10.1509/jm.11.0428.

Han, H., Hsu, L.T.J., Lee, J.S. and Sheu, C. (2011), "Are lodging customers ready to go green? An examination of attitudes, demographics, and eco-friendly intentions", International Journal of Hospitality Management, Vol. 30 No. 2, pp. 345-355, doi: 10.1016/j.ijhm.2010.07.008.

Harlam, B., Krishna, A., LehmanD. and Mela, C. (1995), "Impact of bundle type, price framing and familiarity on purchase intention for the bundle", Journal of Business Research, Vol. 33, pp. 57-66.

Hinz, O., Skiera, B., Barrot, C. and Becker, J.U. (2011), "Seeding strategies for viral marketing: an empirical comparison", Journal of Marketing, Vol. 75 No. 6, pp. 55-71, doi: 10.1509/jm.10.0088.

Homburg, C., Hoyer, W.D. and Stock, R.M. (2007), "How to get lost customers back: a study of antecedents of relationship revival", Journal of the Academy of Marketing Science, Vol. 35, pp. 461-474, doi: 10.1007/s11747-007-0031-7. 
Hu, H.H., Lin, J., Qian, Y. and Sun, J. (2018), "Strategies for new product diffusion: whom and how to target?”, Journal of Business Research, Vol. 83, pp. 111-119, doi: 10.1016/j.jbusres.2017.10.010.

Hughes, A.M. (1996), The Complete Database Marketer, Rev. (Ed.), Irwin Professional Publishing, Chicago.

Hurley, T. (2005a), “Customer retention - practice \& application by Irish leisure facility managers", Leisure Management Ireland Journal, Winter, pp. 15-16.

Hurley, T. (2005b), "The retention intervention - a strategic approach to managing customer retention for leisure facility managers", Leisure Management Ireland Journal, Spring, pp. 14-15.

Irtema, H.I.M., Ismail, A., Berhan, M.N., Das, A.M. and Alshetwi, A.B.Z. (2017), "Case study of the behavioural intentions of public transportation passengers in Kuala Lumpur", Case Studies on Transport Policy, Vol. 6 No. 4, pp. 462-474, doi: 10.1016/j.cstp.2018.05.007.

Janyany, E. and Shivany, S. (2017), "The factors influencing on purchase intention towards beauty care products in Jaffna district”, International Journal of Social Science and Management, Vol. 7 No. 4, pp. 1-13.

Jones, M.A., Mothersbaugh, D.L. and Beatty, S.E. (2003), "The effects of locational convenience on customer repurchase intentions across service types”, Journal of Services Marketing, Vol. 17 No. 7, pp. 701-712.

Kalia, P., Arora, R. and Kumola, S. (2016), "E-service quality, consumer satisfaction and future purchase intentions in e-retail”, E-Service Journal, Vol. 10 No. 1, pp. 24-41, doi: 10.2979/eservicej. 10.1.02.

Kalwani, M. and Yim, C.K. (1992), "Consumer price and promotion expectations: an experimental study", Journal of Marketing Research, Vol. 29 February, pp. 90-100.

Kamakura, M.W., Wedel, M., De Rosa, F. and Mazzon, J.A. (2003), "Cross-selling through database marketing: a mixed data factor analyzer for data augmentation and prediction", International Journal of Research in Marketing, Vol. 20 No. 1, pp. 45-65, doi: 10.1016/s0167-8116(02)00121-0.

Keaveney, S.M. (1995), "Customer switching behaviour in service industries: an exploratory study", Journal of Marketing, Vol. 59 No. 2, pp. 71-82, doi: 10.1177/002224299505900206.

Kim, Y.M. and Park, S.H. (2017), "Conceptualising and measuring the attitudinal loyalty construct in recreation sport contexts", Journal of Sport Management, Vol. 14 No. 3, pp. 197-207, doi: 10. 1123/jsm.14.3.197.

Korgaonkar, P.K., Lund, D. and Price, B. (1985), “A structural equations approach toward examination of store attitude and store patronage behaviour", Journal of Retailing, Vol. 61 No. 2, pp. 39-60.

Koronios, K., Psiloutsikou, M., Kriemadis, A., Gkatsis, G. and Mavromati, M. (2017), "Motivation and high performance sports events: an exploratory investigation of the motives underlying repeated participation", International Journal of Sport Management and Marketing, Vol. 19, pp. 1-2, doi: 10.1108/et-05-2017-0059.

Koronios, K., Psiloutsikou, M. and Kriemadis, A. (2018), "Motives and constraints of participants in running events", Education + Training, Vol. 60 No. 5, pp. 443-457, doi: 10.1108/et-05-2017-0059.

Kumar, V., Shah, D. and Venkatesan, R. (2006), "Managing retailer profitability-one customer at a time!", Journal of Retailing, Vol. 82 No. 4, pp. 277-294, doi: 10.1016/j.jretai.2006.08.002.

Lachowetz, T., Mc Donald, M., Sutton, W. and Clark, J. (2001), "The national basketball association: application of customer lifetime value", Sport Marketing Quarterly, Vol. 10 No. 2, pp. 181-184.

Lichtenstein, D., Burton, S. and Netemeyer, R. (1997), "An examination of deal proneness across sales promotion types: a consumer segmentation perspective”, Journal of Retailing, Vol. 73 No. 2, pp. 283-297.

Lapio, R. and Speter, M. (2000), "NASCAR: a lesson in integrated and relationship marketing", Sport Marketing Quarterly, Vol. 9 No. 2, pp. 85-95.

Lemmens, A. and Gupta, S. (2020), "Managing churn to maximize profits", Marketing Science, Forthcoming, available at SSRN: https://ssrn.com/abstract=2964906.

Incentivizing health club members 
SBM 10,5
Libai, B., Muller, E. and Peres, R. (2013), "Decomposing the value of word-of-mouth seeding programs: acceleration versus expansion”, Journal of Marketing Research, Vol. 50 No. 2, pp. 161-176, doi: 10.1509/jmr.11.0305.

Loureiro, S.M., Miranda, F.J. and Breazeale, M. (2014), "Who needs delight? The greater impact of value, trust and satisfaction in utilitarian, frequent-use retail", Journal of Service Management, Vol. 25 No. 1, pp. 101-124, doi: 10.1509/jmr.11.0305.

Lowe, B. and Barnes, B.R. (2012), "Consumer perceptions of monetary and non-monetary introduction promotions for new products”, Journal of Marketing Management, Vol. 28 Nos 5-6, pp. 629-651, doi: 10.1080/0267257x.2011.560889.

Mela, C., Gupta, S. and Lehmann, D. (1997), "The long-term impact of promotion and advertising on consumer brand choice”, Journal of Marketing Research, Vol. 34 No. 2, pp. 248-261, doi: 10.1177/ 002224379703400205.

Mir, I.A. and Rehman, K.U. (2012), "Two wing models of sales promotion: theorization and examination", Journal of Economics and Behavioural Studies, Vol. 4 No. 1, pp. 12-25, doi: 10. 22610/jebs.v4i1.298.

Moore, M. and Carpenter, J.M. (2008), "Intergenerational perceptions of market cues among US apparel consumers", Journal of Fashion Marketing and Management, Vol. 12 No. 3, pp. 323-337, doi: 10. 1108/13612020810889281.

Murray, D. and Howat, G. (2002), "The relationships among service quality, value, satisfaction, and future intentions of customers at an Australian sports and leisure centre", Sport Management Review, Vol. 5 No. 1, pp. 25-43, doi: 10.1016/s1441-3523(02)70060-0.

Ndubisi, N.O. (2006), "Effect of gender on customer loyalty: a relationship marketing approach", Journal of Marketing Intelligence \& Planning, Vol. 24 No. 1, pp. 48-61, doi: 10.1108/ 02634500610641552 .

Nejad, M.G., Amini, M. and Babakus, E. (2015), "Success factors in product seeding: the role of homophily", Journal of Retailing, Vol. 91 No. 1, pp. 68-88, doi: 10.1016/j.jretai.2014.11.002.

Nusair, K., Yoon, H.J., Naipaul, S. and Parsa, H.J. (2010), "Effect of price discount frames and levels on consumers' perceptions in low end service industries", Journal of Contemporary Hospitality Management, Vol. 22 No. 6, pp. 814-835, doi: 10.1108/09596111011063106.

Olanrewaju, S., Adebiyi, E., Olateju, O. and Bilqis, B.A. (2016), "Improved customer churn and retention decision management using operations research approach", Emerging Markets Journal, Vol. 6 No. 2, pp. 12-21, doi: 10.5195/emaj.2017.131.

Peng, L.Y. and Wang, Q. (2006), "Impact of relationship marketing tactics (RMTs) on switchers and stayers in a competitive service industry", Journal of Marketing, Vol. 22 Nos 1-2, pp. 25-59, doi: 10.1362/026725706776022263.

Peter, J.P. and Olsen, J.C. (1999), Consumer Behaviour and Marketing Strategy, 5th ed., Mc Graw-Hill, Boston.

Phua, J., Jin, S.V. and Kim, J. (2017), "Gratifications of using Facebook, Twitter, Instagram, or Snapchat to follow brands: the moderating effect of social comparison, trust, tie strength, and network homophily on brand identification, brand engagement, brand commitment, and membership intention”, Journal of Telematics and Informatics, Vol. 34 No. 1, pp. 412-424, doi: 10. 1016/j.tele.2016.06.004.

Prayag, G. and Grivel, E. (2014), "Motivation, satisfaction, and behavioral intentions: segmenting youth participants at the Interamnia World Cup 2012", Sport Quarterly, Vol. 23 No. 3, pp. 148-160.

Reinartz, W. and Kumar, V. (2002), "The mismanagement of customer loyalty", Harvard Business Review, Vol. 80 No. 7, pp. 86-94.

Reinartz, W., Kraft, M. and Hoyer, W.D. (2004), "The CRM process: its measurement and impact upon performance”, Journal of Marketing Research, Vol. 14 No. 3, pp. 293-305, doi: 10.1509/jmkr.41.3. 293.35991. 
Rusbult, C.E., Zembrodt, I.M. and Gunn, L.K. (1982), "Exit, voice, loyalty and neglect: responses to dissatisfaction in romantic involvements", Journal of Personality and Social Psychology, Vol. 43 No. 6, pp. 1230-1242, doi: 10.1037/0022-3514.43.6.1230.

Rust, R.T. and Chung, T.S. (2006), "Marketing models of service and relationships", Journal of Marketing Science, Vol. 25 No. 6, pp. 560-580, doi: 10.1287/mksc.1050.0139.

Schmittlein, D.C. and Peterson, R. (1994), "Customer base analysis: an industrial purchase process application”, Marketing Science, Vol. 13, pp. 41-67, doi: 10.1287/mksc.13.1.41.

Seiders, K., Voss, G.B., Grewal, D. and Godfrey, A.L. (2005), "Do satisfied customers buy more? Examining moderating influences in a retailing context”, Journal of Marketing, Vol. 69 No. 4, pp. 26-43, doi: 10.1509/jmkg.2005.69.4.26.

Selin, S.S., Howard, D.R., Udd, E. and Cable, T.T. (1987), "An analysis of consumer loyalty to municipal recreation programs", Leisure Sciences, Vol. 10 No. 3, pp. 217-223, doi: 10.1080/ 01490408809512191.

Söderlund, M. (2006), "Measuring customer loyalty with multi-item scales: a case for caution?", International Journal of Service Industry Management, Vol. 17 No. 1, p. 76-98, doi: 10.1108/ 09564230610651598.

Stauss, B. and Friege, C. (1999), "Regaining service customers", Journal of Research Service, Vol. 1 No. 4, pp. 347-361, doi: 10.1177/109467059914006.

Stavros, C. (2005), Relationship Marketing In Australian Professional Sport; an Organizational Perspective, Doctoral Dissertation, Griffith University, Brisbane, Queensland.

Sudhakar, A. and Rani, T.S. (2013), "Empirical investigation of demographic determinants on consumers' preference of personal care products", Journal of Management Research, Vol. 13 No. 2, pp. 89-104.

Suvattanadilok, M. (2014), "Skin whitening products purchasing intention analysis", Research Journal of Business Management, Vol. 8 No. 1, pp. 28-42, doi: 10.3923/rjbm.2014.28.42.

Tamaddoni, A., Stakhovych, S. and Ewing, M. (2017), "The impact of personalized incentives on the profitability of customer retention campaigns", Journal of Marketing Management, Vol. 33 Nos 5-6, pp. 327-347, doi: 10.1080/0267257X.2017.1295094.

Thomas, J.S., Blatterg, R.C. and Fox, E.J. (2004), "Recapturing lost customers", Journal of Marketing Research, Vol. 41 No. 1, pp. 31-45.

Vafainia, S., Breugelmans, E. and Bimjmolt, T. (2017), "Calling customers to take action: the impact of incentive and customer characteristics on direct mailing effectiveness", Journal of Interactive Marketing, Vol. 45, pp. 62-80, doi: 10.1016/j.intmar.2018.11.003.

Yaghoubi, M., Asgari, H. and Javadi, M. (2017), "The impact of the customer relationship management on organizational productivity, customer trust and satisfaction by using the structural equation model: a study in the Iranian hospitals", Journal of Education and Health Promotion, Vol. 6 No. 6, pp. 14-32, doi: 10.4103/jehp.jehp_32_14.

\section{Appendix}

The appendix is available online for this article.

\section{Corresponding author}

Teresa Hurley can be contacted at: teresa.hurley@tudublin.ie

For instructions on how to order reprints of this article, please visit our website:

www.emeraldgrouppublishing.com/licensing/reprints.htm

Or contact us for further details: permissions@emeraldinsight.com
Incentivizing health club members 